\title{
INNOVATIVE ACTIVITY OF PEDAGOGY
}

\author{
Inoyatkhan Arzimatova
}

Associate Professor, Candidate Of Philosophical Sciences, Fergana State University, Fergana City, Uzbekistan

\section{ABSTRACT}

It is known that pedagogical technology in the learning process is a thematic, sequential, integrated pedagogical process, a goal-oriented, well-designed and guaranteed pedagogical process based on the needs and technical capabilities of young people. Collaborative activity for the realization of the pedagogical goal and the achievement of a guaranteed result depends on the set goal, the chosen content, method, form, means, technology.

In this article, the innovative activity of the educator is scientifically researched.

KEYWORDS:- Pedagogy, education, educational efficiency, innovation, information technology, pedagogical technology, innovative activity.

\section{INTRODUCTION}

As we know that at present interactive methods, innovation technologies and information technologies have been on of important tasks in integrating in education and teaching. Because modern technologies help the youth to gain knowledge, to learn independently, to analyze and make conclusions on the knowledge they gained.

For over the years of independence the Republic of Uzbekistan has carried out fundamental, structural and substantive reforms that have encompassed all levels of education system and its components, which were aimed at ensuring its compliance with the long-term objectives and interests of the country, modern requirements, as well as international standards. The appropriate legal framework reforming this sector was created, which defined as a priority the growth of investment, as well as the investments in human capital, training of educated and intellectually developed generation, which is the crucial asset and a decisive force in the achievement of democratic development, modernization and renewal, ensuring stable and sustainable growth of the economy.

One of the culminating problem while creating the Democratic society is the change of human's education and thinking. The creation of new type of thinking, will become the principal factor of development which is based on the directions democratic society of the person's place and understanding the role in today's progress. Human is a main wealth in every nation. It can be concluded from this, the primary way of improving nation's wealth and power is to increase the each person's own creative skills. Nowadays the amount of money which are spent 
CURRENT RESEARCH JOURNAL OF PEDAGOGICS 2(6): 122-126, June

2021 DOI: https://doi.org/10.37547/pedagogics-crjp-02-06-23

ISSN 2767-3278

(C)2021 Master Journals

\section{Crossref do) 81 Google}

Accepted 25thJune, 2021 \& Published 30 th June, 2021

on education are just not simple expenses, probably they are considered as investments which bring economical income in a fast rate.

\section{Results AND DISCUSSIONS}

In the context of globalization, education plays an important role in the comprehensive development of the individual, in the formation of the qualities of perfection and a qualified specialist. Today's fast-paced period requires equipping learners, including students, with short-term and reliable information, creating the necessary conditions for them to master the basics of various sciences. "Therefore, today in our country special attention is paid to the training of highly spiritual, highly educated specialists that meet international standards. The demand for such specialists in our country will continue to grow in the future too"[1].

The most important elements of modern education have been formed since ancient times. Learning objectives, content, form, methods and tools to analyze the content of educational processes are the traditional categories used. It is these categories that emerge as the subject of pedagogical activity, which constitutes the educational process in a particular subject, specialty or specialty. "Today, education, as in almost any field of human activity, is widely represented by unified and/or special information systems and technologies used by them to solve various tasks in specific areas and activities. And almost always there is a demand for effective use of it, which is clearly associated with the principles and methods inherent in the exact sciences, based on strict formalization - the methodological basis of quantitative assessments, evidence and inference of solutions"[1].

In essence, innovation is a dynamic system of introducing innovation into an attitude or process. Innovation as a system in itself represents the INTERNAL logic of a relationship or process, firstly, and secondly, the gradual development of the innovation being introduced over a period of time and the interaction it has with the environment.

Innovation - is theoretically grounded, focused and practice - oriented innovation. The objectives of the innovative education are:

- Ensuring a high level of intellectual and personal and spiritual development of the student;

- Creation of conditions for mastering the skills they scientific way of thinking;

- Teaching methodology innovations in socioeconomic and professional spheres.

The basis of scientific and technological progress is the inventions and discoveries that are used in various areas of the Organization and lead to the creation of innovations. After practical application, inventions became innovations. They are an active link in all spheres of life and activity of society. Modern space cannot be imagined without such changes. The concept of "innovation" is applied in almost all areas and is a topical issue both at home and at the professional level, including at the level of heads of state and international organizations. "The goal is to get the maximum out of the money and effort spent on innovations in the education system or learning activities. The difference between any innovation and any innovation is that it must have a changing mechanism to manage and control. As in all areas," innovation "in education. , "innovation" and "activities that express their essence" $[2,12]$

The concepts of "new" and "novelty" are important in any innovation important. Innovation introduced into different attitudes and processes is manifested in the form of content specific, subjective, local and conditional ideas. Private innovation involves changing, 
CURRENT RESEARCH JOURNAL OF PEDAGOGICS 2(6): 122-126, June

2021 DOI: https://doi.org/10.37547/pedagogics-crjp-02-06-23

ISSN 2767-3278

(C)2021 Master Journals

\section{Crossref do) 81 Google}

Accepted 25thJune, 2021 \& Published 30th June, 2021

updating, changing one of the elements of an attitude, object or process. Subjective novelty represents the need to update the self of a particular object.

Local innovation serves to describe the practical significance of the innovation being introduced for a particular object. Conditional novelty, on the other hand, serves to shed light on a set of specific elements that enable a complex, progressive update to take place in an attitude, object, or process.

There are unique approaches to the organization of innovation processes in higher education institutions. They are:

1. Individual activity approach (in which teachers, based on their individual capabilities, abilities, experience, achieve a certain consistency in the application of pedagogical innovations in practice).

2. Multi-subject (dialogic) approach (this approach involves the introduction of innovations in the pedagogical process through the interaction of colleagues, in particular, teachers with many years of experience, professionalism and experience, their use of recommendations and guidelines for effective, targeted and continuous use of educational innovations) .

3. Humanistic approach (this approach serves to highlight the expediency of taking into account the level of opportunities, desires, interests, knowledge, skills and abilities of students in the application of innovations in the pedagogical process).

4. Individual-creative approach (according to him, every educator organizes the process of education and upbringing on the basis of creative developments, based on the studied topic, the essence of the educational material, as well as their own capabilities, potential, skills, work experience).
In essence, innovative activity is the creation of a new technological process or a new improved product based on scientific research, development, experimental work, the use of scientific and technical achievements.

The effectiveness of any innovative activity requires the development of the organization in this direction. The content of innovation development management can be expressed by the following rules:

- It is necessary to anticipate and develop innovations;

- it is necessary to accelerate and introduce innovations; it is necessary to prepare for innovations;

- To some extent, the suspension of innovation processes and can be polished;

"Activity is a goal-oriented movement that meets some individual, group, national or universal needs. Pedagogical activity is a socially necessary plan to form universal qualities and national qualities in accordance with a science-based plan to meet the educational needs of society. is a type of activity"[3, 56]. Effectiveness, on the other hand, is that modern pedagogical technologies are available in specific contexts and guarantee the achievement of certain teaching standards, resulting in efficiency, cost-effectiveness.

Innovative activity is the mental, intellectual, physical activity of the teacher requires the acquisition of theoretical knowledge, practical skills and abilities on the basis of focusing their efforts on a specific goal, supplementing practical activities with theoretical knowledge, knowledge, design, development of communicative speech and organizational skills. The law of periodic repetition and repetition of pedagogical innovations represents the renewal of innovations in new, more favorable conditions. In general, the implementation of pedagogical innovations in practice is twofold: 
CURRENT RESEARCH JOURNAL OF PEDAGOGICS 2(6): 122-126, June

2021 DOI: https://doi.org/10.37547/pedagogics-crjp-02-06-23

ISSN 2767-3278

(C)2021 Master Journals

Crossref do: 81 Google

Accepted 25th June, 2021 \& Published 30 ${ }^{\text {th }}$ June, 2021

\section{Conclusion}

In short, the ultimate goal of any teacher's pedagogical activity is to help students become mature individuals with the creative thinking required in modern society.

Today, it is important for educators to have the skills and abilities to innovate. Educators are required to have an innovative approach in order to be able to master the skills of innovative activity. By its very nature, the acquisition of innovative activity skills by educators is based on the decision of an innovative approach.

\section{REFERENCES}

1. Abdurakhmonova, M. M., ugli Mirzayev, M. A., Karimov, U. U., \& Karimova, G. Y. (2021). Information Culture And Ethical Education In The Globalization Century. The American Journal of Social Science and Education Innovations, 3(03), 384-388.

2. Muslimov N.A., Usmonboeva M.H., Sayfurov D.M., Turaev A.B. Innovative educational technologies. Tashkent, 2015.

3. B.Ziyomuhammadov. Pedagogy. Study guide. Tashkent, 2006.

4. B.Xodjaev. On the subject of innovative educational technologies lecture texts. Tashkent, 2015.

5. R.Ishmuhamedov, M.Yuldashev. In education and upbringing innovative pedagogical technologies. Tashkent, $2013 \mathrm{y}$.

6. Normatova D. E. THE SOCIAL AND MORAL VIEWS OF MICHELLE ECKEM DE MONTEN //Scientific Bulletin of Namangan State University. - 2019. - T. 1. - №. 10. - C. 184187.

7. Karimov, U., \& Ergasheva, D. (2020).
EDUCATIONAL ISSUES IN THE PERIOD OF AMIR TEMUR AND TEMURIDS. Теория и практика современной науки, (5), 18-20.

8. Madimarovna, A. I., \& Khoshimovich, M. B. (2020). Factors for the development of tourism culture in the uzbek national value system. ACADEMICIA: An International Multidisciplinary Research Journal, 10(4), 575-580.

9. Каримов, У., Хакимова, Д., \& Халилов, Л. (2018). ИНФОРМАЦИОННОЕ И КОММУНИКАЦИОННОЕ ТЕХНОЛОГИИ ВЛИЯНИЕ НА ОБРАЗОВАНИЕ В ТЕХНИЧЕСКОМ ОБСЛУЖИВАНИЕ. Мировая наука, (10), 193-197.

10. Каримов, У. ИНФОКОМТЕХНОЛ ХАРАКТЕРИСТИК Перспективные $\mathrm{y}$. (2017). (ИКТ) технологии (ПИТ 2017) (pp. 1160-1163).

11. Karimov, U., Kaxarov, S., Yokubjonov, S., \& Ziyodov, D. (2018). USING NEW INFORMATION TECHNOLOGIES IN DISTANCE LEARNING SYSTEM. In HOBAЯ ПРОМЫШЛЕННАЯ РЕВОЛЮЦИЯ В ЗЕРКАЛЕ СОВРЕМЕННОЙ НАУКИ (рp. 911).

12. Каримова, Г. Й. (2018). РОЛЬ КОНСТИТУЦИИ В ПОСТРОЕНИИ ПРАВОВОГО ГОСУДАРСТВА И ГРАЖДАНСКОГО ОБЩЕСТВА. Теория и практика современной науки, (2), 161163.

13. Arzimatova, I. M. (2020). SPIRITUAL CULTURE OF PERSONALITY AND ARTISTIC AND AESTHETIC CHANGES. Scientific Bulletin of Namangan State University, 2(11), 160-165.

14. Karimov, U., \& Abdurakhmon, A. (2017). INNOVATIVE INFORMATION TECHNOLOGY 
CURRENT RESEARCH JOURNAL OF PEDAGOGICS 2(6): 122-126, June

2021 DOI: https://doi.org/10.37547/pedagogics-crjp-02-06-23

ISSN 2767-3278

(C)2021 Master Journals

Crossref do: 81 Google

Accepted 25th June, 2021 \& Published $30^{\text {th }}$ June, 2021

IN EDUCATION. Форум молодых ученых, (5), 9-12.

15. Karimov, U., \& Kasimov, I. (2018). THE IMPORTANCE OF MODERN INFORMATION TECHNOLOGIES IN DEVELOPMENT OF DISTANCE EDUCATION. In Перспективные информационные технологии (ПИТ 2018) (pp. 1186-1187).

16. Normatova, D. E. (2021). The Development Of Socio-Philosophical Thought In Western Europe On The Eve of The End of The Renaissance. The American Journal of Social Science and Education Innovations, 3(03), 371-377.

17. Каримов, У., \& Каримова, Г. (2018). ГЕОПОЛИТИЧЕСКАЯ КОНКУРЕНЦИЯ В ИНФОРМАЦИОННОМ ПРОСТРАНСТВЕ. In Перспективные информационные технологии (ПИТ 2018) (pp. 1368-1372).

18. Arzimatova, I. (2019). AESTHETIC EDUCATION, ITS FEATURES AND STRUCTURE. Scientific Bulletin of Namangan State University, 1(6), 219-222.

19. Karimov, U., \& Ergasheva, D. (2020). EDUCATIONAL ISSUES IN THE PERIOD OF AMIR TEMUR AND TEMURIDS. Теория и практика современной науки, (5), 18-20.

20. Karimov, U. U. (2021). Scientific and Theoretical Foundations of the Formation of the Social Environment in the Family. Oriental Journal of Social Sciences, 37-40.

21. Bozarov, D. M., \& Karimova, G. Y. (2021). ROLE OF THE SELF-ORGANIZATION MODEL IN COMPLEX SOCIAL SYSTEMS. Oriental Journal of Social Sciences, 1-9.

22. Karimov A., Muxammadjonov $X$. INFORMATION TECHNOLOGIES: INFORMATION EDUCATION AND INFORMATICS //Экономика и социум. 2020. - №. 8. - C. 40-43.
23. Arzimatova, I., \& Tursunov, B. (2021). THE ROLE SOCIAL FACTORS IN THE SPIRITUAL DEVELOPMENT PERSONALITY. Scientific Bulletin of Namangan State University, 2(2), 163-170.

24. Arzimatova, I. (2019). Art industry development of society and society culture. Scientific Bulletin of Namangan State University, 1(1), 129-134. 